\title{
Surgical Apgar Score (SAS) Predicts Perioperative Morbidity and Length of Stay in Patients Undergoing Esophagectomy at a High- Volume Center
}

Danica Giugliano, MD

Department of Surgery, Thomas Jefferson University

Andrew Morgan

Department of Surgery, Thomas Jefferson University

Francesco Palazzo, MD

Department of Surgery, Thomas Jefferson University

Nathaniel R. Evans III, M.D.

Department of Surgery, Thomas Jefferson University

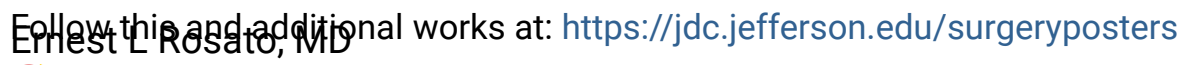

duastmenthef Surgery, Cohpmas Jefferson University

Let us know how access to this document benefits you

See next page for aduditional autithors

\section{Recommended Citation}

Giugliano, MD, Danica; Morgan, Andrew; Palazzo, MD, Francesco; Evans III, M.D., Nathaniel R.; Rosato, MD, Ernest L; Berger, MD, Adam C.; and Leiby, PhD, Benjamin E, "Surgical Apgar Score (SAS) Predicts Perioperative Morbidity and Length of Stay in Patients Undergoing Esophagectomy at a High-Volume Center" (2016). Department of Surgery Posters. 3.

https://jdc.jefferson.edu/surgeryposters/3

This Article is brought to you for free and open access by the Jefferson Digital Commons. The Jefferson Digital Commons is a service of Thomas Jefferson University's Center for Teaching and Learning (CTL). The Commons is a showcase for Jefferson books and journals, peer-reviewed scholarly publications, unique historical collections from the University archives, and teaching tools. The Jefferson Digital Commons allows researchers and interested readers anywhere in the world to learn about and keep up to date with Jefferson scholarship. This article has been accepted for inclusion in Department of Surgery Posters by an authorized administrator of the Jefferson Digital Commons. For more information, please contact: JeffersonDigitalCommons@jefferson.edu. 


\section{Authors}

Danica Giugliano, MD; Andrew Morgan; Francesco Palazzo, MD; Nathaniel R. Evans III, M.D.; Ernest L Rosato, MD; Adam C. Berger, MD; and Benjamin E Leiby, PhD 


\section{Surgical Apgar Score (SAS) Predicts Perioperative Morbidity and Length of Stay in Patients Undergoing Esophagectomy at a High-Volume Center}

Department of Surgery ${ }^{1}$ and Biostatistics and Clinical Pharmacology ${ }^{2}$, Thomas Jefferson University, Philadelphia, PA 19107

\section{Background/Methods}

\section{Background}

Esophagectomy is a procedure that carries considerable morbidity. Many studies have evaluated factors to predict patients at risk and improve clinical outcomes. The aim of this study was to determine whether the SAS predicts complications, length of stay, and anastomotic leak for patients undergoing esophagectomy at a high-volume institution.

\section{Methods}

We evaluated 212 patients undergoing successful esophagectomy between January 2005 and April 2014.

Postoperative complications were graded using a modification of the Clavien-Dindo scale $^{1}$, and the SAS (range 0-10), modified from Gawande et al. ${ }^{2}$, was determined. Association of SAS with incidence of anastomotic leak and complications was evaluated using the Cochran Armitage trend test between grouped SAS scores (0-2, 3-4, 5-6, 7-8, 9-10) and each of the outcomes. Correlation of Apgar score with length of stay was evaluated using competing risks proportional hazards regression.

\begin{tabular}{|l|c|}
\hline \multicolumn{2}{|c|}{$\begin{array}{l}\text { Table 1. Patient characteristics, procedures, } \\
\text { and 30-day outcomes }\end{array}$} \\
\hline n (range or \%) \\
\hline Preoperative variables: & \\
\hline No. of included patients & 212 \\
\hline Age (mean (years)) & $63.5(31-86)$ \\
\hline Gender (male) & $175(82.5)$ \\
\hline ASA (mean) & $2.86(2-4)$ \\
\hline \begin{tabular}{l} 
Intraoperative variables: \\
\hline $\begin{array}{l}\text { Lowest heart rate } \\
\text { (mean (beats/min)) }\end{array}$
\end{tabular} & $58.7(20-105)$ \\
\hline $\begin{array}{l}\text { Lowest mean arterial pressure } \\
\text { (mean (mmHg)) }\end{array}$ & $54.6(30-85)$ \\
\hline $\begin{array}{l}\text { Estimated blood loss } \\
\text { (mean (mL)) }\end{array}$ & $300.0(50-4000)$ \\
\hline $\begin{array}{l}\text { Operative duration } \\
\text { (mean (min)) }\end{array}$ & $445.4(156-738)$ \\
\hline Operative Procedures: & \\
\hline Open & $84(39.6)$ \\
\hline $\begin{array}{l}\text { Minimally Invasive } \\
\text { Esophagectomy }\end{array}$ & $128(60.4)$ \\
\hline Postoperative outcomes: & $83(39.2)$ \\
\hline No complications & $62(29.2)$ \\
\hline Minor complications (Clavien 1,2) & $56(26.4)$ \\
\hline Major complications (Clavien 3,4) & $11(5.2)$ \\
\hline Deaths (Clavien 5) & \\
\hline
\end{tabular}

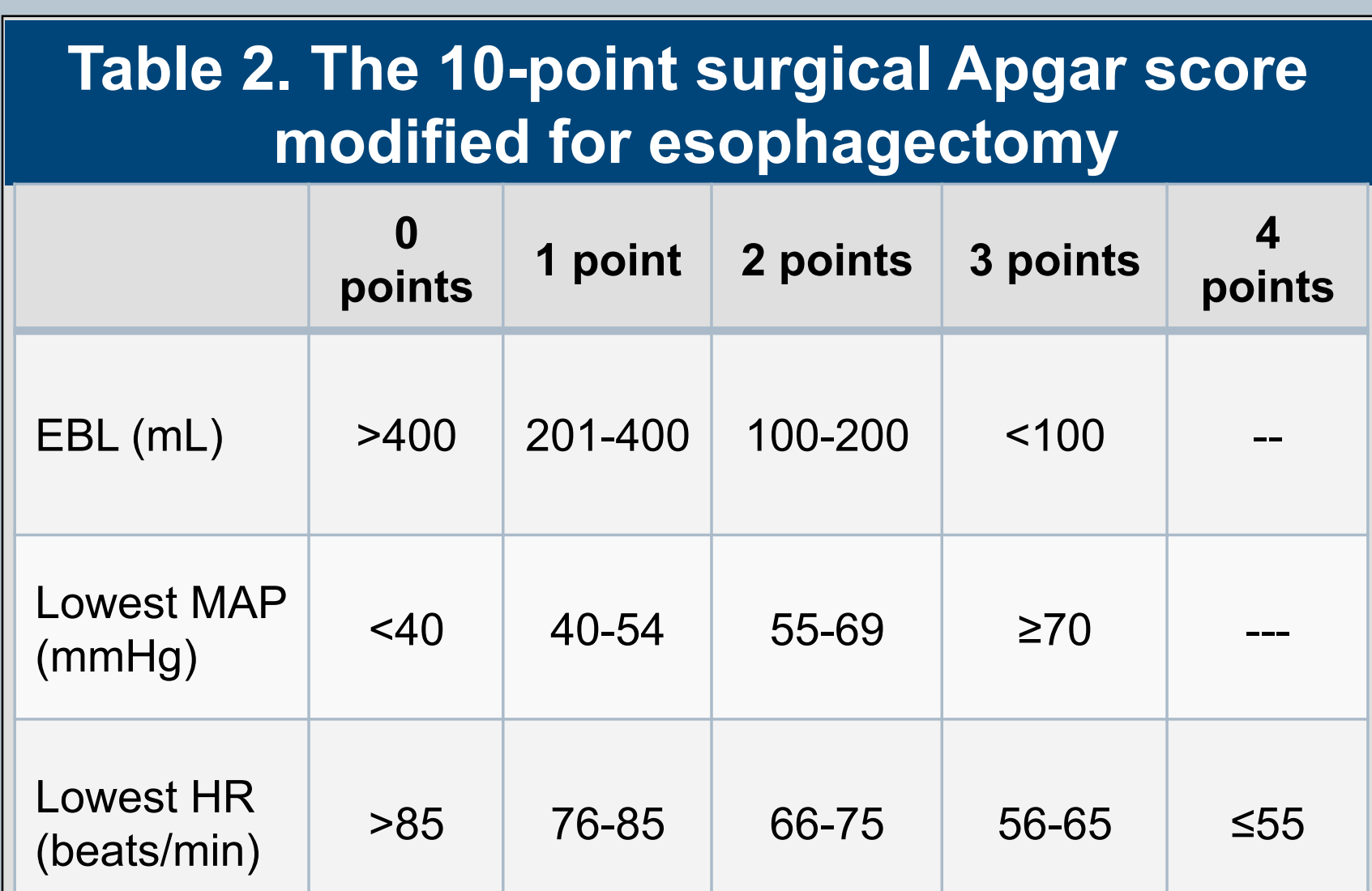

Table 3. Incidence of anastomotic leak and complications by surgical Apgar score category

\begin{tabular}{|c|c|c|c|c|c|}
$\begin{array}{c}\text { Surgical } \\
\text { Apgar } \\
\text { Scare }\end{array}$ & $\mathbf{n}$ & $\begin{array}{c}n(\%) \text { with } \\
\text { Anastomotic } \\
\text { Leak }\end{array}$ & $\begin{array}{c}n(\%) \text { with } \\
\text { Grade } 2 \text { or } \\
\text { Higher } \\
\text { Complication }\end{array}$ & $\begin{array}{c}n(\%) \text { with } \\
\text { Grade } 3 \text { or } \\
\text { Higher } \\
\text { Complication }\end{array}$ & $\begin{array}{c}n(\%) \text { with } \\
\text { perioperative } \\
\text { death }\end{array}$ \\
\hline $0-2$ & 5 & $2(40)$ & $5(100)$ & $3(60)$ & $1(20)$ \\
\hline $3-4$ & 23 & $6(26)$ & $17(74)$ & $15(65)$ & $4(17)$ \\
\hline $5-6$ & 81 & $12(15)$ & $81(56)$ & $27(33)$ & $5(6)$ \\
\hline $7-8$ & 96 & $17(18)$ & $43(45)$ & $22(23)$ & $1(1)$ \\
\hline $9-10$ & 7 & $1(14)$ & $1(14)$ & $0(0)$ & $0(0)$ \\
\hline \multicolumn{2}{|c|}{$\begin{array}{c}\text { Trend test p- } \\
\text { value }\end{array}$} & 0.29 & 0.0002 & $<0.0001$ & 0.0006 \\
\hline
\end{tabular}

Table 4. Median length of hospital stay

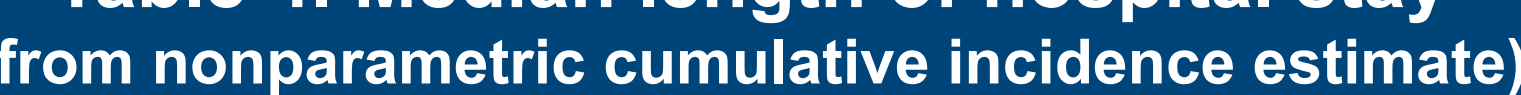

\begin{tabular}{|c|c|}
\hline Surgical Apgar Score & Median LOS (days) \\
\hline ALL & 18.5 \\
\hline $0-2$ & 20 \\
\hline $3-4$ & 16 \\
\hline $5-6$ & 10 \\
\hline $7-8$ & 9 \\
\hline $9-10$ & 8 \\
\hline Trend test p-value & $<0.0001$ \\
\hline
\end{tabular}

\section{Results}

- The average patient age was 63.5 years (range 31-86), and the average blood loss was $300 \mathrm{~mL}$ (range $50-4000$ ). The median length of

- There was a significant association between SAS and Grade 2 or higher $(p=0.0002)$ and Grade 3 or higher $(p<0.0001)$ complications, but not with anastomotic leak $(p=0.29)$ (Table 3 ).

- The perioperative mortality rate was $5.2 \%$ $(n=11)$ with lower SAS being associated with greater mortality (Table 3).

- Length of stay was also associated with SAS ( $p<0.0001$ ) with higher scores being associated with shorter length of stay (Table 4).

- Minimally-invasive esophagectomy was associated with a lower rate of anastomotic leak $(p=0.0047)$ and of Grade 3 or higher complication $(p=0.0071)$, independent of SAS.

- Adjustment for age did not change the significance of the associations.

\section{Conclusions}

- We demonstrate that SAS is a significant predictor of complications and length of stay for patients undergoing esophagectomy.

- The SAS should be used to identify patients at lower risk in order to prioritize use of postoperative critical care beds and hospital resources.

\section{References}

[1] Dindo D, Demartines N, Clavien PA. Classification of surgical complications. A new proposal with evaluation in a cohort of 6336 21 Gawande AA Kwann MR, Regnengen SE, 24psiz SA Zinner MJ. An apgar score for surgery. J Am Coll Surg. 2007; 204(2): stay was 18.5 days (Table 4 ) 